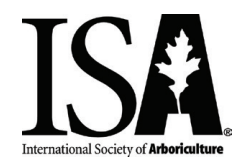

Arboriculture \& Urban Forestry 2018. 44(2):87-100

\title{
A Volunteer and Partnership Baseline for Municipal Forestry Activity in the United States
}

\author{
Richard J. Hauer, Nilesh Timilsina, Jess Vogt, Burnell C. Fischer, \\ Zach Wirtz, and Ward Peterson
}

\begin{abstract}
Communities cultivate citizen support of municipal forestry operations through volunteers and partnerships. Through a national census and survey of urban forestry activity in over 660 municipalities in the United States, researchers found two-thirds of all responding communities involve volunteers in tree activities. This increases from half of small communities $(2,500$ to 4,999 people) to all large communities (one million or more people) involving volunteers. When tabulated for the United States, a mean national estimate of 345,466 (195,754 SEM) people volunteered 1,484,204 (665,460 SEM) hours with municipal tree activities. This equates to 714 (320 SEM) full-time equivalent (2,080 hour-base year) positions. Overall, volunteers completed nearly $5 \%$ of municipal tree care activities. Nearly $80 \%$ of the municipalities train their volunteers. Tree planting ( $85 \%$ of communities) was the most common activity, followed by tree watering (40\%), awareness/education programs $(39 \%)$, tree pruning (28\%), and fundraising (20\%). Findings were contrasted with U.S. census population groups to disaggregate if volunteerism varied by community size. Volunteers were more commonly involved in communities with a greater urban-forestry capacity derived from a sustainability index score. Six attributes of municipal forestry program had either positive $(+)$ or negative $(-)$ effect on volunteer participation in urban forestry activities. These included adequate budget $(-)$, per capita spending $(-)$, tree board $(+)$, outreach $(+)$, strategic plan $(+)$, and total employment $(+)$.

Key Words. Civic Science; Municipal Forestry; Partnership; Volunteer.
\end{abstract}

The urban forest results from many social and environmental human activities (Miller et al. 2015). People, through their decisions, policies, plans, and actions are the primary agent influencing the trees that grow in built environments. Community tree populations result from trees existing prior to development, natural regeneration, and through trees planted by humans (Nowak et al. 2004; Miller et al. 2015). Collectively, the urban forest results from people who plant, maintain, and remove trees through varying levels of activity across public and private land (Miller et al. 2015; Vogt et al. 2015). In the context of public land, public employees, contracted companies, and volunteers are three primary ways that urban forestry activity happens (Johnson et al. 2016; Peterson and Hauer 2016). 'Activity' in this sense is defined as any effort to maintain urban tree populations in a built environment. In the United States, Hauer and Peterson (2016) found that $54 \%$ of the time associated with tree activities occurs through public employees. Contractors accounted for $41 \%$ of time associated with urban forestry activities. Volunteers represented 5\% of the time with activities. The implications of volunteer activity within municipal forestry programs is a focus of this paper.

Volunteerism in general has been relatively well studied, with Musick and Wilson (2008) and Wilson (2012) writing about such activities in their recent reviews. Individuals with certain personality traits (e.g., extraversion, agreeableness, resilience, and empathy when accompanied by a feeling of obligation) are more likely than others to volunteer (Wilson 2012). Other studied predictors of volunteering include an interest in overcoming identity problems (by joining a like community of volunteers), a desire to benefit themselves through display of volunteer status to friends and acquaintances, and a previous religious experience (Wilson 2012). Additionally, studies have observed that women are more likely to volunteer than men, Caucasians volunteer at higher rates than other racial or ethnic groups, 
citizens more likely than non-citizens, those in good health more than those in poor health, and more highly educated and higher-income earners than those less educated or of lower income (Wilson 2012). Lastly, research on the volunteer sector has observed that social context and surrounding community matters: people with larger social networks volunteer more, including students and those with school associations, and homeowners and others more tightly connected to their neighborhood volunteer more than renters or less connected individuals (Wilson 2012). Ethnically diverse areas experience lower volunteer rates.

In the urban forestry sector, volunteering one's time for civic engagement and community betterment is not a new concept (Ball 1986; Makra and Andresen 1990; Westphal and Childs 1994; Johnson 1995; Hauer et al. 2017). Historical evidence of tree activities to benefit a community by people receiving no compensation goes back many centuries and likely several millennia (Hauer et al. 2017). Lipkis and Lipkis (1990) wrote about the important role that civic engagement plays in urban forestry through the simple act of planting a tree to heal a neighborhood. Similarly, Krasny and Tidball (2015) discuss the practices and impacts of "civic ecology" (actions to steward or restore the environment, such as tree planting, gardening, etc.) by volunteers. Voluntary civic-ecology practices, these authors argue, have benefits not only for ecosystem services, but also to the well-being of people, for encouraging social learning, generating networks and partnerships, and restoring communities (Krasny and Tidball 2015). In a recent study on tree-planting volunteerism associated with New York City's MillionTreesNYC initiative, Fisher et al. (2015) stated that, "There is an implicit claim related to ... residents' actions [volunteering to plant trees] that quality of life in cities is, in part dependent upon preservation of the local environment" (p. 3). Fisher et al. (2015) observed that volunteers who planted trees also had high levels of broader civic engagement (with other organizations, at rallies, voting, etc.). Evidently, the reasons for people getting involved with urban forests include a variety of social and environmental factors (Nesbitt et al. 2017; Ordóñez et al. 2017).

Volunteers may have any of a number of motivations for their participation or engagement in urban forestry activities. Participating in local tree-planting and follow-up care involves working with nature and can result in a strong social connection to other participants (Westphal 1993; Austin 2002). The belief that participants are helping the environment is another stronger motivation of volunteer engagement (Bruyere and Rappe 2007). Westphal (1993) discovered that emotional, aesthetic, and psychological values of trees, rather than benefits derived from property values or the cooling effects of trees, motivated volunteer TreeKeeper participants in Chicago, Illinois, U.S. In Toronto, Canada, Conway (2016) similarly found resident motivations for tree planting were primarily aesthetic rather than for ecosystem services. Regardless of the reasons, engagement in urban forestry is more likely when volunteers know, or are educated about, the importance of the topic (Moskell et al. 2010).

There are many reasons urban forestry professionals may incorporate volunteers in urban forest activities (Still and Gerhold 1997). Civic engagement builds community connections (Lipkis and Lipkis 1990; Portney 2005; Elmendorf 2008; Moskell et al. 2010; Krasny and Tidball 2015). City residents become more satisfied with the outcome of public street trees when the resident planted the street tree compared to residents who had a street tree planted by the city (Sommer et al. 1994). People tend to have a greater sense of pride when involved with stewardship projects (Mincey and Vogt 2014). Volunteers can possibly initiate and/ or complete projects that would otherwise not occur due to a lack of resources (McPherson and Johnson 1988; Bloniarz and Ryan 1996; Miles et al. 1998; Snyder and Omoto 2008; Pincetl 2010; Moskell et al. 2016). Community involvement may also lead to greater tree survival (Sklar and Ames 1985; Mincey and Vogt 2014; Widney et al. 2016).

Volunteerism provides participants with a sense of satisfaction, a sense of place within a community, and results in a better place to live (Still and Gerhold 1997; Snyder and Omoto 2008). Community engagement may also facilitate social recovery following a natural disaster with a treeplanting activity used to memorialize the loss associated with the storm (Tidball et al. 2010; Krasny and Tidball 2015). Storms (e.g., hurricanes, ice storms, tornadoes) are common events that affect 
tree loss annually in populated environments (Hauer et al. 2011a). Ultimately, for the many reasons that incorporating volunteers is important, Summit and Sommer (1998) suggest the activity needs to be easy to engage and must provide personal advantages to best encourage participation.

Even though civic engagement has important values, approximately $75 \%$ of the United States population did not volunteer their time in any activity in 2015 (BLS 2016). Moskell and Allred (2013) found in two New York City, New York, U.S., neighborhoods that the majority (over 60\%) of residents believe the government should be responsible for tree stewardship. However, nearly half of municipal foresters indicated that funding is not sufficient to meet identified needs (Hauer and Peterson 2016).

In light of the importance of volunteers to sustainable urban forestry programs, this study sought to assess the incorporation of volunteers within the United States through five research goals. First, researchers set out to describe the current state of volunteer incorporation into municipal forestry programs. Second, the activity areas that volunteers undertook was quantified. Third, researchers identified informal partnerships through organizations within a community as part of the public tree program. Fourth, researchers determined whether program strength using an urban forestry sustainability model was associated with the likelihood to incorporate volunteers. Finally, attributes were ascertained that predict incorporating volunteers in municipal forestry program, using logistic regression methods.

\section{METHODS}

\section{Sampling Design}

Tree activities in municipalities in the United States were estimated for 7,478 census-designated places. A total 1,727 places were sampled for this research, based on a national study conducted by Hauer and Peterson (2016). A complete census of all communities with 50,000 or more people occurred, with all places asked to participate. All census-designated places below 50,000 people were randomly sampled at a lower intensity: $50.9 \%$ of communities between 25,000 and 49,999 people and $10.3 \%$ of communities between 2,500 and 24,999. The sampling approach and intensity was consistent with four previous municipal tree management projects (Ottman and Kielbaso 1976; Giedraitis and Kielbaso 1982; Kielbaso et al. 1988; Tschantz and Sacamano 1994) in the United States. The sampling design for all places at the national level relates to a person and the likelihood that they live in a place conducting any of the municipal forestry and tree care activities ascertained in the study. Within a population group (e.g., 2,500 to 4,999 people), the design allows interpretation at both the person and the community level. In the cases that reporting involves the percent of all communities $(n=7,478)$ associated with a study question, researchers adjusted by weighting of smaller communities (e.g., 2,500 to 4,999) to account for the sampling percent used. By example, for the 2,500 to 4,999 population group, Weight Factor $=1 /(\%$ Sampled $/ 100) ; 9.7261=1$ / $(10.2816 / 100)$; whereas \% sampled $=($ sample size/total population; $10.2861=(241 / 2344) *$ 100. Likewise, adjustments were made for other population groups by the methods above, following the approach of Hauer and Peterson (2016).

The primary person associated with community tree activities was asked to participate. The list was created by initially asking each state urban and community forestry (U\&CF) group, with contact information supplied by 41 coordinators. In nine states where researchers were unable to obtain contact information, and in places that $U \& C F$ coordinators were unable to provide contact information, the final list was created by searching a community website to identify a person (e.g., city forestry, parks manager, public works director, city clerk) who directs community tree activities. A paper-based questionnaire was sent by the U.S. Postal Service using methods by Dillman et al. (2014) to the identified primary person. Both long- and short-form questionnaires containing 109 and 53 questions, respectively, were sent as part of the study, including questions, to ascertain volunteer involvement with tree care activities. The survey was conducted in 2014. In brief, a pre-letter explaining the project was followed by a second mailing with the long-form questionnaire and a self-addressed return envelope. A third reminder (postcard) was sent to non-respondents. A fourth contact, with a replacement long-form questionnaire and a self-addressed stamped envelope, was sent to non-respondents. A fifth reminder e-mail 
was sent to locations where an e-mail was available. A sixth mailing with a replacement short version of the questionnaire was sent. A total of $667 \mathrm{com}$ munities (38.6\%) responded, and this was slightly higher than two previous municipal tree care surveys in 1986 (38.1\%), by Kielbaso et al. (1988), and in 1993 (34.1\%), by Tschantz and Sacamano (1994). The Institutional Review Board associated with this study was involved to approve the protocol for the study. No non-respondent bias was discerned in this study as determined by comparing results from this study with equivalent published results. For example, the total volunteer hours reported in this study were consistent with results collected by the United States Department of Agriculture Forest Service (USDA-FS) Urban and Community Forestry Program in the study year.

\section{Statistical Approach}

Each research question was crafted a priori to implementation of the study analysis. These questions included: 1) What volunteer capacity occurred in municipal forestry in 2014 (e.g., total number, total hours, full-time equivalents, mean time per person)? 2) What activity areas do volunteers participate in (e.g., tree boards, tree maintenance types, advocacy, fundraising, policy), and if training is provided? 3) What organizations were involved with community tree management partnerships (e.g., individual residents, civic organizations, neighborhood associations, business associations, school groups/youth organizations, nonprofit groups, municipal governance group, and utilities)? These three questions were further disaggregated by population (group) of communities.

The fourth question ascertained if community strength of their urban forestry program was related to volunteer incorporation into municipal forestry activity. Each community was given an index score using a model of urban forestry sustainability (Clark et al. 1997). A total 19 of 20 index areas were used, each with a 1 to 4 score possible, with a composite index score ranking between 19 and 76. The native vegetation criteria in the vegetation resource component was unable to be ascertained in this study. The composite index score was derived from summing the three component (category) groups that relate to resource management, community framework, and vegetation resource criteria (Clark et al. 1997). The index score was used to test the hypothesis that more advanced programs (interpreted as a higher index score) were more likely to incorporate volunteers (Ha: Programs with greater score more likely to incorporate volunteers). ANOVA were performed to compare communities on number of volunteers used, amount of volunteer hours used, and urban forestry sustainability index score. As a test, if volunteers were a replacement for a municipal forestry program, $\chi^{2}$ analysis was further used to ascertain if communities that did not conduct public tree activity were more likely to incorporate volunteers. An $\alpha \leq 0.05$ significance level was used to detect a difference for both statistical tests.

The fifth research question identified if attributes of a municipal forestry program explained if a community engages volunteers. Logistic regression was used to model whether a community involved volunteers in urban forest/tree management activities against seventeen predictors (Table 1). Initial preliminary models used an $\alpha \leq 0.25$ significance level to determine if a variable potentially explained volunteer inclusion. Through subsequent model refinements, the best model was selected based on the significance of individual predictors and the Akaike information criteria (AIC) value of the models (Hosmer et al. 2013). Researchers also used the ANOVA function (glm) in R (version 3.3.1) to compare nested models. Overall significance of the model was tested using $\chi^{2}$ goodness-of-fit test (Hosmer et al. 2013); researchers also used residual plot (both Pearson and deviance) to examine model fit (Hosmer et al. 2013). Researchers also used receiver operating curve (ROC) and area under ROC to evaluate model fit (Hosmer et al. 2013). Finally, a combination of backward and forward selection procedures were then used to examine the best model, and to determine if initially excluded variables provided explanation as interpreted with an $\alpha \leq 0.05$ significance level, with no previously excluded variables found to be significant.

\section{RESULTS}

Communities in the United States commonly incorporated volunteers and informal partnerships with organizations into municipal tree activities 
Table 1. Variables used as a predictor of volunteer involvement in urban tree/forest management.

\begin{tabular}{|c|c|c|}
\hline $\begin{array}{l}\text { Code } \\
\text { variable }\end{array}$ & Variable description & $\begin{array}{l}\text { Percent or mean } \\
\text { (standard deviation) }\end{array}$ \\
\hline Volt & Community works with volunteers or partners & $65.4 \%$ \\
\hline Pop & Community population from 2010 census & $91,871(339,889)$ \\
\hline Foract & $\begin{array}{l}\text { Community conduct any kind of shade tree/urban } \\
\text { and community forestry activities }\end{array}$ & $86.0 \%$ \\
\hline Cetarb & Community has ISA Certified Arborist staff & $60.9 \%$ \\
\hline Degree & Staff has degree (two, four, or masters) & $56.5 \%$ \\
\hline Totemp & Total employee & $10.0(16.3)$ \\
\hline Contractor & Paid contractors used & $87.7 \%$ \\
\hline Adbudget & Budget adequate to meet current identified need & $52.5 \%$ \\
\hline Trboard & $\begin{array}{l}\text { Community has government authorized tree board, } \\
\text { parks board, city department, etc. }\end{array}$ & $67.1 \%$ \\
\hline Ordinance & $\begin{array}{l}\text { Municipality have one or more municipal ordinances } \\
\text { that pertain to trees }\end{array}$ & $91.0 \%$ \\
\hline Strgplan & $\begin{array}{l}\text { Community have a written strategic plan for } \\
\text { urban forestry }\end{array}$ & $50.3 \%$ \\
\hline Voltrain & Volunteers receive training & $45.2 \%$ \\
\hline Treeinven & Community have a tree inventory & $66.6 \%$ \\
\hline Systematic & Community have systematic tree care activities & $45.4(34.3)$ \\
\hline Rskmgmt & $\begin{array}{l}\text { Community conducts tree risk management (hazard } \\
\text { tree identification) }\end{array}$ & $57.3 \%$ \\
\hline Outreach & $\begin{array}{l}\text { Municipal staff provide educational presentation } \\
\text { to city residents }\end{array}$ & $59.4 \%$ \\
\hline Treecity & Community is a Tree City USA & $73.0 \%$ \\
\hline Percapita & Per capita budget & $0.52(0.50)$ \\
\hline
\end{tabular}

across public lands. Nearly two-thirds (65\%) of respondents indicated that volunteers take part in public tree activities (Figure 1). Thus, nationally, $65 \%$ of people live in a community that engages people to volunteer in public tree management. This ranged from $52 \%$ of communities in the smallest places $(2,500$ to 4,999 people) to $100 \%$ of communities with one million or more people reporting such. Seventy-nine percent of communities trained volunteers prior to implementing an urban forestry activity. As community size increased, the commonality of training increased from approximately $50 \%$ in the smallest population groups $(2,500$ to 9,999 people) to $100 \%$ in places with 500,000 or more people (data not shown).

Tree planting was the most common activity that involved volunteers and partner organizations in $85 \%$ of reporting communities (Figure 1). Population groups were similar with most exceeding $80 \%$ inclusion of volunteers for tree planting in their communities. Watering trees was reported for $40 \%$ of communities, with most population groups between $30 \%$ and $44 \%$ inclusion. Tree pruning occurred in $28 \%$ of communities, varying among population groups with no discernable trend. Pest management and tree removal were uncommon with just $3 \%$ and $9 \%$ of communities, respectively.
Interestingly, $35 \%$ of places in the smallest population group (2,500 to 4,999 people) indicated volunteer involvement with tree removal, with no responding community of 500,000 or more people using volunteers to assist with tree removal. Volunteers also provide service through awareness and education programs (39\%), fundraising (20\%), and management and policy development (18\%). There were no discernible differences among population groups (data not shown).

A variety of organizations informally partner and help communities to carry out tree care activities (Figure 2). Individual residents involved in an organized tree care or management activity were most common in $60 \%$ of reporting communities. Organized groups that were commonly involved include school groups or youth organizations, such as $4-\mathrm{H}$ and scouting organizations (55\%), nonprofit groups (50\%), and neighborhood associations (44\%). Service of volunteers through tree-related governance groups involved park/tree boards (48\%), city council/village boards (37\%), and beatification committees (28\%).

The number of people and amount of time that volunteers provided communities is displayed in Table 2. On average, 205.0 people are annually involved with a municipality in a volunteer 


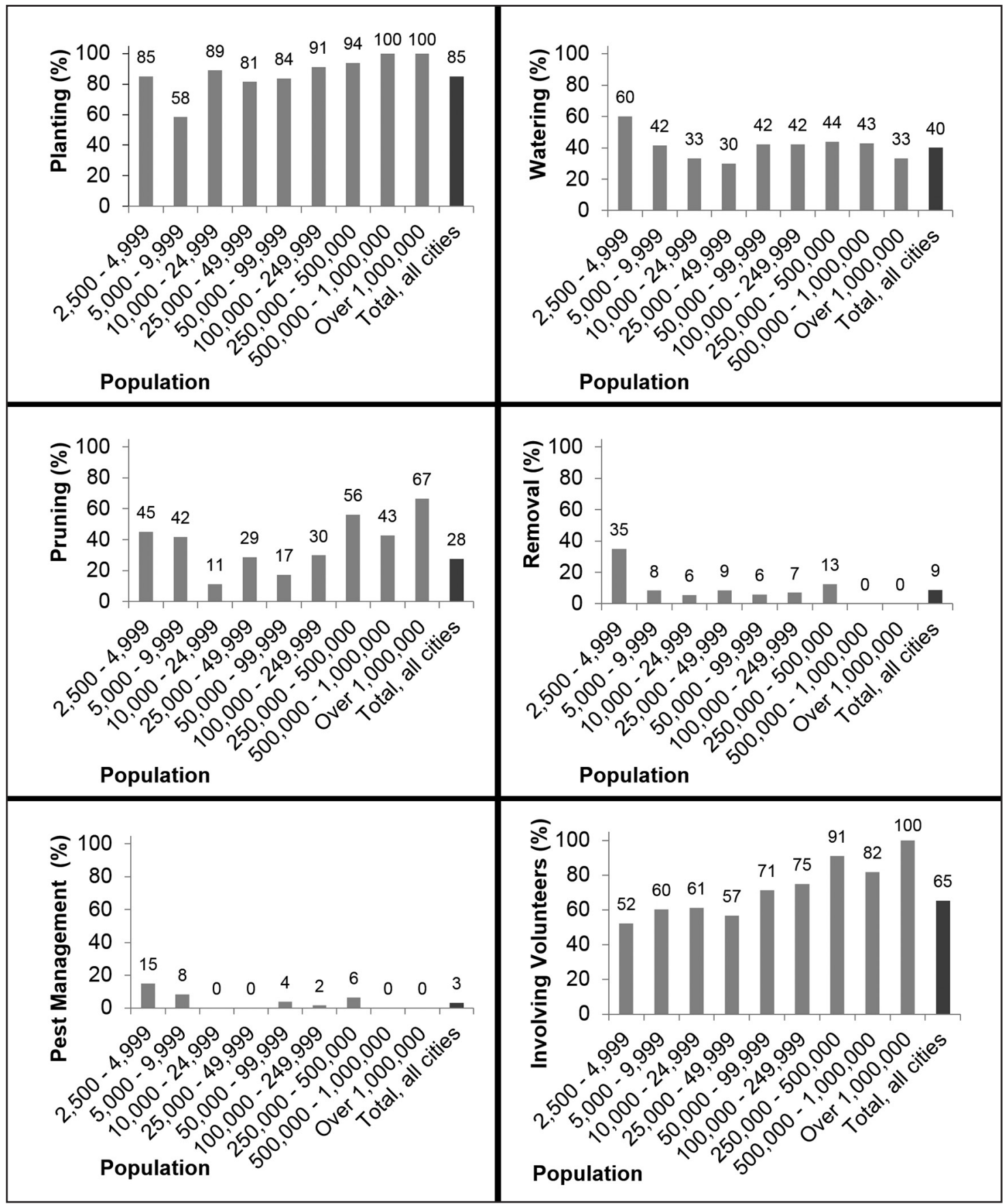

Figure 1. Percentage of communities that involve volunteers $(n=644$; individuals or groups not paid for providing services) for tree activities ( $n=307$; tree planting, watering, pruning, removal, and pest management) on public property.

role. Not surprising, fewer people on average volunteered in smaller communities $(2,500$ to 4,999 people group, 34.2 people, $18.2 \mathrm{SEM})$ than larger places (500,000 to 999,000 population group, 525.5 people, $311.3 \mathrm{SEM})$ in some capacity $(\mathrm{F}=7.308$; $\mathrm{df}=8,207 ; P<0.0001)$. Expressed on a per 1,000 people basis, 3.22 (0.92 SEM) people per 1,000 people volunteered. This decreased from 10.9 (0.64 SEM) people per 1,000 in the smallest population group to 0.55 (0.42 SEM) people per 1,000 in places with $1,000,000$ or more people. Nationally, an estimated 345,466 (195,754 SEM) people volunteered.

The number of volunteer hours increased from the smallest to largest cities, with a national esti- 
mated mean of 852.3 (174.3 SEM) hours of volunteer time occurring in a community (Table 2). This increased from a few hundred hours on average per small communities to several thousand hours in larger communities $(\mathrm{F}=10.321$; $\mathrm{df}=8$, 194; $P<0.0001)$. Expressing volunteerism on a mean time per person basis, 9.82 hours (1.38 SEM) per person occurred. There was no difference in time per person among population groups $(\mathrm{F}=$ 1.528; $\mathrm{df}=8,191 ; P=0.15)$. People volunteered an estimated 1,484,204 (665,460 SEM) hours with municipal tree activities. Stated another way, these volunteered hours equate to 714 (320 SEM) full-time equivalents (2,080 hour-base year).

Communities that incorporated volunteers into their urban forestry activities ranked higher with a sustainability index $(\mathrm{F}=13.952 ; \mathrm{df}=1$, $447 ; P<0.001)$ than locations not involving volunteers (Table 3 ). The composite score for communities with volunteers scored 46.1 (0.43 SEM) compared to 42.7 (0.50 SEM) in locations not using volunteers. The community framework component had the strongest difference $(\mathrm{F}=$ 17.652; $\mathrm{df}=1,447 ; P<0.0001)$, scoring $16.4(0.23$

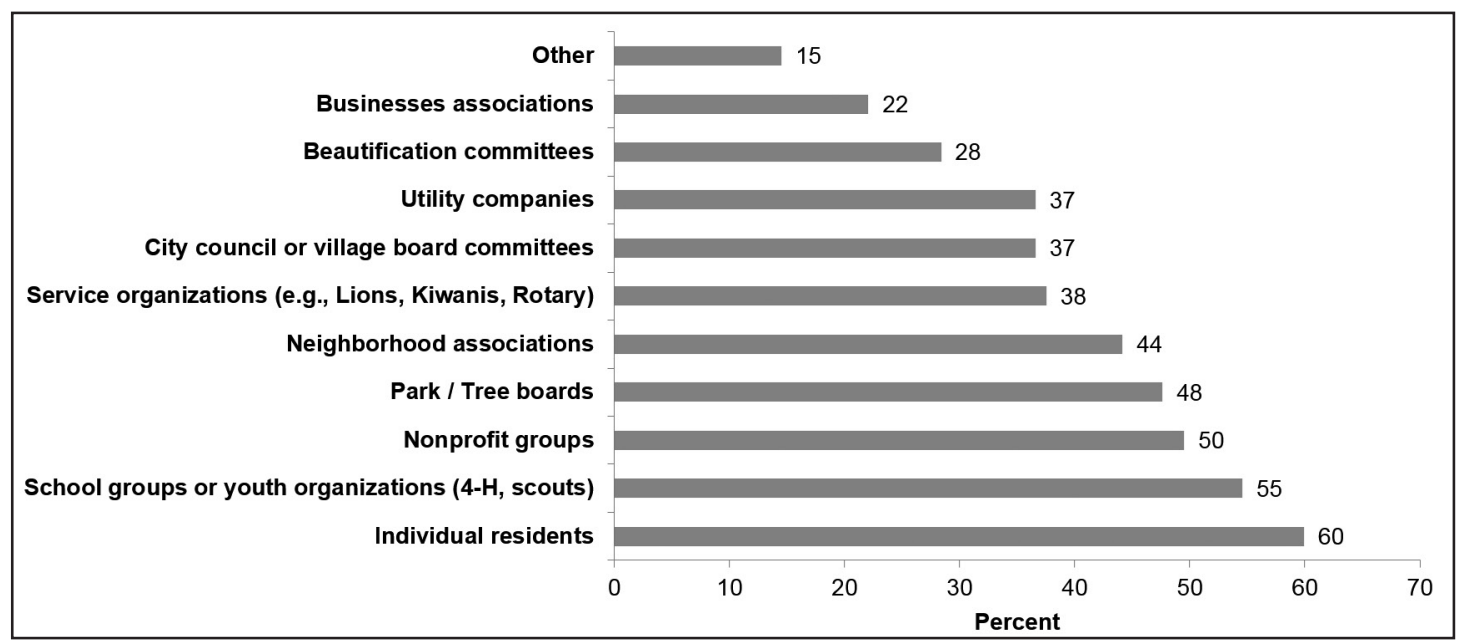

Figure 2. Organizations that help communities to carry out tree care or management $(n=317)$.

Table 2. Mean number of volunteers and volunteer hours along with standard error of the mean (SEM) for different population groups and geographic regions that were ascertained for information related to urban trees/forest management activities in the United States.

\begin{tabular}{|c|c|c|c|c|c|c|c|}
\hline Classification & $\begin{array}{l}\text { Sample size } \\
(\mathrm{n})\end{array}$ & $\begin{array}{l}\text { Mean number } \\
\text { of people (\#) }\end{array}$ & $\begin{array}{l}\text { Mean time } \\
\text { all people } \\
\text { (hours) }\end{array}$ & $\begin{array}{l}\text { Mean time per } \\
\text { person (hours) }\end{array}$ & $\begin{array}{l}\text { SEM of number } \\
\text { of people }(\#)\end{array}$ & $\begin{array}{l}\text { SEM of time } \\
\text { all people } \\
\text { (hours) }\end{array}$ & $\begin{array}{l}\text { SEM of time } \\
\text { per person } \\
\text { (hours) }\end{array}$ \\
\hline Total, all cities & 216 & 205.0 & 852.3 & 9.82 & 56.1 & 174.3 & 1.38 \\
\hline \multicolumn{8}{|l|}{ Population Group } \\
\hline 2,500 to 4,999 & 16 & 34.2 & 270.4 & 26.16 & 18.2 & 124.5 & 13.17 \\
\hline 5,000 to 9,999 & 11 & 31.0 & 158.7 & 6.99 & 14.6 & 71.9 & 1.38 \\
\hline 10,000 to 24,999 & 14 & 37.6 & 158.3 & 8.42 & 15.0 & 69.1 & 3.02 \\
\hline 25,000 to 49,999 & 52 & 211.5 & 368.4 & 9.48 & 151.7 & 139.3 & 2.11 \\
\hline 50,000 to 99,999 & 65 & 119.1 & 631.5 & 9.14 & 52.8 & 209.0 & 2.22 \\
\hline 100,000 to 249,999 & 41 & 251.9 & 1089.7 & 7.40 & 64.6 & 243.0 & 1.89 \\
\hline 250,000 to 499,000 & 11 & 324.1 & 3087.2 & 8.03 & 166.7 & 1830.2 & 3.72 \\
\hline 500,000 to 999,999 & 4 & 525.5 & 2606.8 & 3.71 & 311.3 & 1227.2 & 0.51 \\
\hline $1,000,000+$ & 2 & 4068.5 & 12,538 & 4.76 & 3879.5 & 11,306 & 1.76 \\
\hline \multicolumn{8}{|l|}{ Geographic Region } \\
\hline Midwest & 77 & 60.9 & 378.5 & 8.42 & 13.7 & 108.7 & 1.40 \\
\hline Northeast & 29 & 325.1 & 1508.6 & 20.75 & 272.8 & 907.4 & 8.45 \\
\hline South & 46 & 149.0 & 1052.6 & 8.61 & 51.4 & 467.5 & 1.98 \\
\hline West & 64 & 364.2 & 971.4 & 7.45 & 136.7 & 227.4 & 1.32 \\
\hline
\end{tabular}


SEM) with volunteers, compared to 14.6 (0.37 SEM) without. The vegetation resource component was also significantly greater $(F=6.376$; $\mathrm{df}=1,447 ; P=0.012$ ) in communities including volunteers. A marginal difference was found in the resource management $(P=0.067)$ component, again scoring higher in communities that engage volunteers into municipal forestry.

The final logistic model to test for a relationship between inclusion of volunteers and a variety of parameters was overall significant $\left(\chi^{2}=55.7\right.$; df $=6 ; P<0.001 ; \mathrm{AIC}=336.32)$. Residual plots did not show any problems with model fit, and area under the ROC curve was 0.76 , indicating a good discriminatory power of the model. Six variables significantly explained whether a municipality involved volunteers in urban forest/tree management, out of the seventeen tested in the logistic regression model (Table 4 ). If a community indicated their budget was adequate $(P=0.016)$ based on identified needs, the odds of volunteer participation decreased by $50 \%$. Furthermore, an increase in the tree budget on a per capita $(P<$ $0.0001)$ basis reduced the odds of volunteer participation by $72 \%$. Communities that have a tree board ( $P=0.045)$ were more likely to involve volunteers, increasing the odds of volunteer involvement by $91 \%$ (Table 1$)$. Outreach $(P=0.008)$ activities increased the odds of volunteer participation by $115 \%$. Similarly, having a strategic plan $(P=0.046)$ also increased the odds of participa- tion by $77 \%$. Interestingly, volunteer participation did not decrease the number of employees working in the forestry program in a community. Rather, an increase in the number of total employees $(P=0.018)$ increased the odds of volunteer participation by $4 \%$. Program activity matters as only $38.5 \%$ of the communities that stated they did not formally conduct municipal tree activities had volunteers conduct activities $\left(\chi^{2}=35.5\right.$; $\mathrm{df}=$ $1,630 ; P<0.0001)$, compared $70.5 \%$ of communities that formally conducted municipal activities.

\section{DISCUSSION}

This is the first known study to investigate volunteer capacity within municipal forestry programs across the United States. Case studies have addressed local and regional volunteer efforts (Miller et al. 2015; Vogt et al. 2015; Moskell et al. 2016; Morgenroth and Östberg 2017), but not national enumeration, with the exception of annual volunteer hours listings by the USDA-FS (2016). From the current study, nearly two-thirds of people in the United States live in a community that involves volunteers in some municipal tree activity. Thus, an opportunity to volunteer is strong.

This study estimated that people volunteered 1.48 million hours in some municipal tree capacity within the United States. The USDA-FS Urban \& Community Forestry program annually collects data from State U\&CF coordinators about munici-

Table 3. The comparison of community sustainability index scores in locations without volunteer and those with volunteers. Sustainability index score derived from the model developed by Clark et al. (1997), $n=449$.

\begin{tabular}{|c|c|c|c|c|}
\hline & Without volunteers & With volunteers & & \\
\hline Index score & Mean (SEM) & Mean (SEM) & F-statistic & $P$-value \\
\hline Resource management & $20.99(0.44)$ & $21.91(0.28)$ & 3.364 & 0.067 \\
\hline Community framework & $14.60(0.37)$ & $16.35(0.23)$ & 17.652 & 0.000 \\
\hline Vegetation resource & $7.13(0.16)$ & $7.81(0.13)$ & 6.376 & 0.012 \\
\hline Composite score & $42.72(0.50)$ & $46.07(0.43)$ & 13.952 & 0.000 \\
\hline
\end{tabular}

Table 4. Coefficients (log odds) and odds ratio of a logistic regression of volunteer participation in urban forest management, $\mathrm{n}=309$.

\begin{tabular}{|c|c|c|c|c|c|}
\hline Coefficient & Estimate & SE & $P$-value & Odds ratio & $\begin{array}{l}\text { Odds ratio } 95 \% \\
\text { confidence interval }\end{array}$ \\
\hline Intercept & 0.1833 & 0.4166 & 0.6599 & 1.2012 & $0.5308-2.7183$ \\
\hline Adbudget & -0.6736 & 0.2783 & 0.0155 & 0.5099 & $0.2955-0.8797$ \\
\hline Trboard & 0.6492 & 0.3239 & 0.0450 & 1.9141 & $1.0145-3.6115$ \\
\hline Outreach & 0.7689 & 0.2919 & 0.0084 & 2.1574 & $1.2175-3.8231$ \\
\hline Percapita & -1.2482 & 0.3005 & $<0.0001$ & 0.2870 & $0.1593-0.5173$ \\
\hline Strgplan & 0.5761 & 0.2892 & 0.0464 & 1.7791 & $1.0093-3.1361$ \\
\hline Totemp & 0.0440 & 0.0186 & 0.0182 & 1.0449 & $1.0075-1.0838$ \\
\hline
\end{tabular}


pal forestry programs. In FY 2014, a total 1.39 million volunteer hours was reported by all 50 states through the state U\&CF programs (NUCFAC 2015; USDA-FS 2015; USDA-FS 2016). Thus, the findings from this study were $6 \%$ higher-by 91,107 hours-but within the confidence intervals of the findings. Cumulatively, for all 50 states, eight territories, and Washington, D.C., a total 1.48 million volunteer hours were logged. Thus, this study validates one of the data outputs that state U\&CF coordinators report annually to the USDA-FS.

This study also quantified attributes of a municipal forestry program that explained whether a community incorporates volunteers into municipal forestry activities. Communities that expressed their budget was adequate were less likely to incorporate volunteers. Unsurprisingly, communities with a higher per-capita budget were also less likely to include volunteers. One could conclude that perhaps volunteers are a replacement for staff in communities that suggested they were underfunded (McPherson and Johnson 1988; Bloniarz and Ryan 1996; Moskell et al. 2016). This study did not support the claim that volunteers replaced municipal staff. Overall, the total number of employees was greater in programs that included volunteers compared to those that did not. Researchers also found communities with no formal tree activity conducted by municipal employees in the study period had a $45 \%$ reduction in volunteer engagement. Volunteers also did not act as a replacement for contracted tree work, overall, and no difference in contracting occurred among the volunteer-including and non-including communities (Hauer and Peterson 2016). This is consistent with the attitude of residents in New York City, who believe stewardship of park trees and street trees is best managed by the government/public programs (Moskell and Allred 2013).

The strength of a municipal forestry program corresponded to volunteer inclusion. The Clark et al. (1997) model was used to gauge program strength. The model gives a relative index for a community along a continuum that ranks a program for its direction toward a sustainable program. Communities with a higher index on average were more likely to include volunteers. It is possible that volunteers helped provide a mechanism to improve a community along the continuum. For example, assisting with a tree inventory, providing expertise to construct a tree ordinance, fostering greater connections to neighborhood associations, and other variables in the index model, would elevate a community's ranking. The other possibility is that a community with greater municipal forestry capacity is better positioned to work with volunteers (Hauer and Johnson 2008; Hauer et al. 2011b). Having a tree board and having a strategic plan were both associated with the greater odds of volunteer inclusion, and these attributes are important for municipal forestry management (Miller et al. 2015). This may partially be explained by people on municipal boards who often serve in a volunteer capacity. Thus, it seems logical that the tree board variable was a significant explanatory variable.

Outreach was an important part of explaining volunteer involvement. Not having an outreach program does not mean a community will not involve volunteers. Rather, communities that had an outreach program were two times more likely to include volunteers in urban forestry activities. Making it easy for volunteers to join enhances the prospects for volunteer participation (Summit and Sommer 1998). Outreach provides a way to educate people on why they should volunteer, which enhances recruitment (Moskell et al. 2016). Overcoming barriers to participate is also important. For example, community-based health volunteers were more likely to stop volunteering when logistical issues and a lack of supplies hamper their work (Chatio and Akweongo 2017).

Training personnel prior to conducting tree activities is important for proper implementation of work. The efficacy of volunteers properly conducting an activity, perhaps as compared to professional standards, is important for quality control (Bloniarz and Ryan 1996; Galloway et al. 2006). Bloniarz and Ryan (1996) found 83\% agreement between trained volunteers and certified arborists assessing the condition of trees. When disagreements occur, volunteers were more likely to rate a tree lower in condition than a certified arborist. Student volunteers in Oregon, U.S., were able to measure a quantitative attribute, such as tree diameter, similarly to professionals (Galloway 2006). Qualitative assessment, such as tree-crown class, was significantly different between the student volunteers and professionals. Ball et al. (2007) found 
that Master Gardeners trained in collecting treeinventory data did well in collecting tree-inventory information. Interestingly, the highest error rate occurred with $3.7 \%$ incorrectly recording of the property address. Tree identification to the species level was correct $98.8 \%$ of the time. Bloniarz and Ryan (1996) found that trained volunteers identified correctly to the species $80 \%$ of the time, and to the genera $94 \%$ of the time. Roman et al. (2017) found that citizen scientists and experts were consistent with $84.8 \%$ of identified tree species. Thus, regardless if one is a volunteer or professional, the credential and/or training of a person is important for precise and accurate measurements (Miller et al. 2015; Morgenroth and Östberg 2017). This study found training was common to the majority $(80 \%)$ of communities that engage volunteers. Thus, trained volunteers are vital to effectively conduct tree activities. Training is also important if communities engage citizen science with urban forestry research questions (Roman et al. 2017).

In the United States, approximately one in four people volunteered for one or more activities in 2015 (BLS 2016). Collectively, a total 7.8 billion hours were logged by these 62.6 million volunteers. Compared to the volunteer hours estimated in this study, $0.02 \%$ of all volunteering time in the United States was for public tree activities. A decline in volunteerism in general has occurred over the past several decades to $24.9 \%$ of the population in September 2015 (BLS 2016). Whether this trend has occurred in urban forestry is not known, as the current study provides the first national volunteer assessment in municipal forestry for baseline comparison.

Involving volunteers engages citizens to become better connected to a community through urban forestry activities. The citizen involvement in TreesCount!, a 2015 campaign in New York City, illustrates how a well-developed volunteer effort can successfully implement a tree activity. A total 2,241 trained volunteers inventoried $34 \%$ of the 660,000 street tree population (Cochran and Greer 2016). Involvement of volunteers through tree planting (85\%) was the most common activity, followed by watering ( $40 \%)$, per this study. The high rate of tree planting is not surprising considering the estimated number of communities with Tree City USA recognition in this study was con- sistent with the 3,400 communities recorded by the Arbor Day Foundation (Hauer and Peterson 2016). The Tree City USA program requires an Arbor Day observance and proclamation as one of the four standards, and a tree-planting event is a common part of Arbor Day. Formative maintenance of trees after planting during establishment is important. Mincey and Vogt (2014) found volunteer watering of newly planted trees was more successful (e.g., greater tree survival) when done collectively, through signed agreements and when monitoring and sanctioning occurred. Roman et al. (2015) found excellent tree survival (95.4\% to $99.4 \%$ annual survival) with volunteer tree planting. They attributed this to stewardship practices and training at tree planting, as well as maintenance during the establishment period.

Volunteer tree pruning was less common (28\%) in the current study, however, in some locations, citizen-pruner programs are well-structured with a rich history. Citizen-pruner programs are an example approach to engage volunteers into municipal forestry, with New York City, for example, establishing a program in 1976 (Moll and Ebenreck 1989). Several other examples exist in municipalities in other states as well (e.g., California, Michigan, and Minnesota). Not every community engages citizens in all municipal forestry activities, and those undertaken are likely a reflection of community needs and interests.

This study also indicated the importance of volunteering in smaller communities, which tend to have less volunteer participation. Less than half (42\%) of communities with fewer than 5,000 people have money specifically allocated for municipal tree management (Hauer and Peterson 2016). These communities most likely have an insufficient budget and would benefit from volunteer participation.

The study also speaks to the likelihood of communities incorporating volunteers into activities around urban forestry. That is, the level of analysis is the community. This means researchers cannot say anything about the motivations for individual volunteers' participation in urban forestry activities. Future studies on volunteerism in urban forestry should more thoroughly investigate why individuals might participated in urban forestry activities, as well as the influence of the demographic and social factors 
mentioned herein (e.g., gender, race, ethnicity) on individual likelihood of volunteering.

\section{CONCLUSION}

This study provides the current volunteer capacity in municipal forestry in the United States. Nearly two-thirds of people live in a community that involves volunteers. Many tree activities involve volunteers, with tree planting as the most common activity, while the more technically challenging activities, such as tree removal, being less common. Developing an outreach program leads to more likely involvement of volunteers in a community. The community ranking along an urban forest sustainability index was greater in communities that involved volunteers.

Whether volunteers lead to a stronger program, whether stronger programs are more likely to include volunteers, or whether this relationship is ultimately a combination of factors, is not known from this study. Finally, the 0.345 million people who volunteered nearly 1.5 million hours of time equate to over 700 full-time staff. The volunteer hours reported in this study were consistent with data reported to the USDA-FS, lending confirmation of state U\&CF reported data, or likewise confirmation of this study's findings. People tended to volunteer, on average, ten hours of time annually. Thus, it is unlikely that volunteers would be able to comprise the entire municipal forestry program. Rather, strong programs tend to involve volunteers.

Researchers found that volunteers do not appear to be a substitute for municipal staff or contracted services; rather, they are an addition, typically evident through a planned administrative structure (strategic plan and outreach). Volunteers might lead to increased municipal staff time needed to develop volunteer outreach and training within the urban forestry area. Finally, communities that spent more as reflected by per capita spending and budget adequacy were less likely to involve volunteers.
Acknowledgments. Funding for this project was provided by the TREE Fund, Wisconsin Arborist Association, University of Wisconsin-Stevens Point (UWSP) College of Natural Resources, UWSP Office of Sponsored Research, USDA-Forest Service, and the USDA

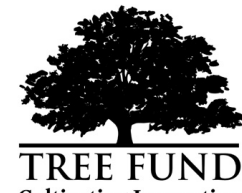

Cultivating Innovation
McIntire-Stennis Program. We also thank two anonymous reviewers for their comments that improved this paper. Finally, our thanks are extended to the Municipal Tree Care and Management in the United States project review team members: Julia Bartens, Carrie Gallagher, Joe Gregory, Burney Fischer, Gary Johnson, Dana Karcher, Wes Kocher, Andrew Koeser, Ed Macie, Jack McCabe, Paul Ries, Phil Rodbell, Jim Skiera, Pete Smith, and Jess Vogt.

\section{LITERATURE CITED}

Austin, M.E. 2002. Partnership opportunities in neighborhood tree planting initiatives: Building from local knowledge. Journal of Arboriculture 28(4):178-186.

Ball, J. 1986. Urban forestry and volunteer management. Journal of Arboriculture 12(7):182-184.

Ball, J., S. Mason, A. Kiesz, D. McCormick, and C. Brown. 2007. Assessing the hazard of emerald ash borer and other exotic stressors to community forests. Arboriculture \& Urban Forestry 33(5):350-359.

Bloniarz, D.V., and H.D.P. Ryan III. 1996. The use of volunteer initiatives in conducting urban forest resource inventories. Journal of Arboriculture 22(2):75-82.

BLS. 2016. Volunteering in the United States-2015. U.S. Bureau of Labor Statistics News Release USDL-16-0363.

Bruyere, B., and S. Rappe. 2007. Identifying the motivations of environmental volunteers. Journal of Environmental Planning and Management 50(4):503-516.

Chatio, S., and P. Akweongo. 2017. Retention and sustainability of community-based health volunteers' activities: A qualitative study in rural Northern Ghana. PLoS ONE 12(3):e0174002. $<$ https://doi.org/10.1371/journal.pone.0174002>

Clark, J.R., N.P. Matheny, G. Cross, and V. Wake. 1997. A model of urban forest sustainability. Journal of Arboriculture 23(1):17-30.

Cochran C., and B. Greer. 2016. TreesCount! 2015: NYC's Third Street-Tree Census. Accessed 03 July 2017. <http://nysufc.org/ treescount/2016/04/26>

Conway, T.M. 2016. Tending their urban forest: Residents' motivations for tree planting and removal. Urban Forestry \& Urban Greening 17(1):23-32.

Dillman, D.A., J.D. Smyth, and L.M. Christian. 2014. Internet, Phone, Mail, and Mixed-Mode Surveys: The Tailored Design Method, fourth edition. John Wiley \& Sons Inc, Hoboken, New Jersey, U.S. 528 pp.

Elmendorf, W. 2008. The importance of trees and nature in community: A review of relative literature. Arboriculture \& Urban Forestry 34(3):152-156.

Fisher, D., E. Svendsen, and J. Connolly. 2015. Urban Stewardship and Civic Engagement: How planting Trees Strengthens the Roots of Democracy. Routledge Press, New York, New York, U.S. 131 pp.

Galloway, A.W.E., M.T. Tudor, and W.M. Vander Haegen. 2006. The reliability of citizen science: A case study of Oregon white oak stand surveys. Wildlife Society Bulletin 34(5):1425-1429. 
Giedraitis, J.P., and J.J. Kielbaso. 1982. Municipal Tree Management. Urban Data Service Reports. Volume 14(1). International City Management Association. Washington, D.C. 16 pp.

Hauer R.J., and W.D. Peterson. 2016. Municipal Tree Care and Management in the United States: A 2014 Urban \& Community Forestry Census of Tree Activities. Special Publication 16-1, College of Natural Resources, University of Wisconsin-Stevens Point. 71 pp.

Hauer, R.J., A.J. Hauer, D.R. Hartel, and J.R. Johnson. 2011a. Rapid assessment of tree debris following urban forest ice storms. Arboriculture \& Urban Forestry 37(4):237-247.

Hauer, R.J., and G.R. Johnson. 2008. Approaches within the 50 United States to meeting federal requirements for urban and community forestry assistance programs. Arboriculture \& Urban Forestry 34(2):74-83.

Hauer, R.J., G.R. Johnson, and M.I. Kilgore. 2011b. Local outcomes of federal and state urban and community forestry programs. Arboriculture \& Urban Forestry 37(4): 152-159.

Hauer, R.J., R.W. Miller, L.P. Werner, and C.C. Konijnendijk van den Bosch. 2017. The History of Trees in the City. pp. 17-32. In: F. Ferrini, C.C. Konijnendijk van den Bosch, and A. Fini (Eds.). Routledge Handbook of Urban Forestry. Routledge Press, Abingdon, United Kingdom. 548 pp.

Hosmer, D.W., Jr, L. Stanley, and R.X. Sturdivant. 2013. Applied Logistic Regression, third edition. John Wiley \& Sons, Inc., Hoboken, New Jersey, U.S. 528 pp.

Johnson, G., R. Hauer, W. Peterson, D. Karcher, and J. Gulick. 2016. Financing the urban forest: Volunteers as a source of revenue and program Support. Arborist News 25(4):20-25.

Johnson, G.R. 1995. Tree care advisor: A voluntary stewardship program. Journal of Arboriculture 21(1):25-32.

Kielbaso, J.B., B.S. Beauchamp, K.F. Larison, and C.J. Randall. 1988. Trends in Urban Forestry Management. Baseline Data Report. Volume 20(1). International City Management Association. Washington, D.C. 20 pp.

Krasny, M.E., and K.G. Tidball. 2015. Civic Ecology: Adaptation and Transformation from the Ground Up. The MIT Press, Cambridge, Massachusetts, U.S. 293 pp.

Lipkis, A., and K. Lipkis. 1990. The Simple Act of Planting a Tree: A Citizen Forester's Guide to Healing Your Neighborhood, Your City, and Your World. Jeremy P. Tarcher, Inc., Los Angeles, California, U.S. 237 pp.

Makra, E.M., and J.W. Andresen. 1990. Neighborwoods: Volunteer community forestry in Chicago. Arboricultural Journal 14(2):117-127.

McPherson, E.G., and C.W. Johnson. 1988. A community forestry planning process: Case study of citizen participation. Landscape and Urban Planning 15(1-2):185-194.

Miles, I., W.C. Sullivan, and F.E. Kuo. 1998. Ecological restoration volunteers: The benefits of participation. Urban Ecosystems 2(1):27-41.

Miller, R.W., R.J. Hauer, and L.P. Werner. 2015. Urban Forestry Planning and Managing Urban Greenspaces, third edition. Waveland Press, Long Grove, Illinois, U.S. 560 pp.

Mincey, S.K., and J.M. Vogt. 2014. Watering strategy, collective action, and neighborhood planted trees: A case study of Indianapolis, Indiana, U.S. Arboriculture \& Urban Forestry 40(2):84-95.
Moll, G., and S. Ebenreck, 1989. Shading Our Cities: A Resource Guide for Urban and Community Forests. Island Press, Washington, D.C., U.S. 333 pp.

Morgenroth, J., and J. Östberg. 2017. Measuring and Monitoring Urban Trees and Urban Forests. pp. 17-32. In: F. Ferrini, C.C. Konijnendijk van den Bosch, and A. Fini (Eds.). Routledge Handbook of Urban Forestry. Routledge Press, Abingdon, United Kingdom.

Moskell C., N. Bassuk, S. Allred, and P. MacRae. 2016. Engaging residents in street tree stewardship: Results of a tree watering outreach intervention. Arboriculture \& Urban Forestry 42(5):301-317.

Moskell, C., and S.B. Allred. 2013. Residents' beliefs about responsibility for the stewardship of park trees and street trees in New York City. Landscape and Urban Planning 120:85-95.

Moskell, C., S. Broussard Allred, and G. Ferenz. 2010. Examining volunteer motivations and recruitment strategies for engagement in urban forestry. Cities and the Environment 3(1):article 9. Accessed 22 June 2017. <http://escholarship.bc.edu/cate/ vol3/iss $1 / 9>$

Musick, M.A., and J. Wilson. 2008. Volunteers: A Social Profile. Indiana University Press, Bloomington, Indiana, U.S. 680 pp.

Nesbitt, L., N. Hotteb, S. Barron, J. Cowanc, and S.R.J. Sheppard. 2017. The social and economic value of cultural ecosystem services provided by urban forests in North America: A review and suggestions for future research. Urban Forestry \& Urban Greening 25(July 2017):103-111.

Nowak, D.J., M. Kuroda, and D.E. Crane. 2004. Tree mortality rates and tree population projections in Baltimore, Maryland, USA. Urban Forestry \& Urban Greening 2:139-147.

NUCFAC. 2015. Ten-Year Urban Forestry Action Plan: 2016-2026. $259 \mathrm{pp}$.

Ordóñez, C., T. Beckley, P.N. Duinker, and A.J. Sinclair. 2017. Public values associated with urban forests: Synthesis of findings and lessons learned from emerging methods and cross-cultural case studies. Urban Forestry \& Urban Greening 25(July 2017):74-84.

Ottman, K.A., and J.J. Kielbaso. 1976. Managing Municipal Trees, Urban Data Service Reports. Volume 8(11). International City Management Association, Washington, D.C. 16 pp.

Peterson, W., and R. Hauer. 2016. Getting work done in the urban forest: Community staffs, volunteers, and contractors. Arborist News 25(6):34-38.

Pincetl, S. 2010. Implementing municipal tree planting: Los Angeles million-tree initiative. Environmental Management 45(2):227-238.

Portney, K. 2005. Civic engagement and sustainable cities in the United States. Public Administration Review 65:579-591.

Roman, L.A., B.C. Scharenbroch, J.P.A Ostberg, L.S. Mueller, J.G. Henning, A.K. Koeser, and J.R. Sanders, et al. 2017. Data quality in citizen science urban tree inventories. Urban Forestry \& Urban Greening 22:124-135.

Roman, L.A., L.A. Walker, C.M. Martineau, D.J. Muffly, S.A. MacQueen, and W. Harris. 2015. Stewardship matters: Case studies in establishment success of urban trees. Urban Forestry \& Urban Greening 14:1174-1182.

Sklar, F., and R.G. Ames. 1985. Staying alive: Street tree survival in the inner-city. Journal of Urban Affairs 7(1):55-66. 
Snyder, M., and A.M. Omoto. 2008. Volunteerism: Social issues perspectives and social policy implications. Social Issues and Policy Review 2:1-36.

Sommer, R., F. Leary, J. Summit, and M. Tirrell. 1994. The social benefits of resident involvement on street-tree planting. Journal of Arboriculture 20(3):170-175.

Still, D.T., and H.D. Gerhold. 1997. Motivations and task preferences of urban forestry volunteers. Journal of Arboriculture 23(3):116-130.

Summit, J., and R. Sommer. 1998. Urban tree-planting programs: A model for encouraging environmentally protective behavior. Atmospheric Environment 32(1):1-5.

Tidball, K.G., M.E. Krasny, E.S. Svendsen, L.K. Campbell, and K. Helphand. 2010. Stewardship, learning, and memory in disaster resilience. Environmental Education Research 16(5-6):591-601.

Tschantz, B.A., and P.L. Sacamano. 1994. Municipal Tree Management in the United States. Davey Resource Group and Communication Research Associates, Inc. Report, Kent, Ohio, U.S. 58 pp.

USDA-FS. 2015. Budget and Community Accomplishment Reporting System (CARS) Summary Report FY 2015. Accessed 13 July 2017. <www.stateforesters.org/sites/default/files/publicationdocuments/UCF\%20Committee $\% 205 \% 2015 \% 20$ CARS\%20 FY\%202010_2015\%20Summary\%20Report\%20_OSEC.pdf>

USDA-FS. 2016. Community Accomplishments Reporting System for Urban \& Community Forestry Program National FY 2014 Summary, CARS version 1.6.05. Accessed 30 July 2017. <https:// apps.fs.usda.gov/nicportal>

Vogt, J.M., S.L. Watkins, S.K. Mincey, M. Patterson, and B.C. Fischer. 2015 Explaining planted-tree survival and growth in urban neighborhoods: A study of recently-planted trees in Indianapolis. Landscape \& Urban Planning 136:130-143.

Westphal, L. 1993. Why trees? Urban forestry volunteers values and motivations. p. 19-23. In: P.H. Gobster (Ed.). Managing Urban and High-Use Recreation Settings, Fourth North American Symposium on Society and Resource Management, 17-20 May 1992, University of Wisconsin, Madison, Wisconsin. North Central Forest Experiment Station, St. Paul, Minnesota, U.S.

Westphal, L., and G. Childs. 1994. Overcoming obstacles: Creating volunteer partnerships. Journal of Forestry 92(10):28-29, 31-32.

Widney, S., B.C. Fischer, and J. Vogt. 2016. Tree mortality undercuts ability of tree-planting programs to provide benefits. Forests 7(3):65. < doi:10.3390/f7030065>

Wilson, J. 2012. Volunteerism research: A review essay. Nonprofit and Voluntary Sector Quarterly 41(2):176-212. < doi: 10.1177/0899764011434558>

Richard J. Hauer (corresponding author)

University of Wisconsin-Stevens Point

College of Natural Resources-Forestry

800 Reserve Street

Stevens Point, Wisconsin, U.S

Nilesh Timilsina

University of Wisconsin-Stevens Point

College of Natural Resources-Forestry

Stevens Point, Wisconsin, U.S.
Jess M. Vogt

Department of Environmental Science \& Studies

College of Science \& Health, DePaul University

Chicago, Illinois, U.S.

Burnell C. Fischer

Indiana University, Bloomington

School of Public and Environmental Affairs

Bloomington, Indiana, U.S.

Zach Wirtz

Undergraduate Research Assistant

University of Wisconsin-Stevens Point

Stevens Point, Wisconsin, U.S.

Ward Peterson

Davey Tree Experts

Davey Resource Group

Aurora, Ohio, U.S.

Résumé. Les communautés entretiennent le soutien des citoyens aux opérations forestières municipales par le biais de bénévoles et de partenariats. Grâce à un recensement national et à une étude sur l'activité de la foresterie urbaine dans plus de 660 municipalités américaines, les chercheurs ont constaté que les deux tiers des communautés ayant répondu au sondage faisaient appel à des bénévoles pour des activités arboricoles. Il en ressort que la moitié des petites communautés ( 2500 à 4999 personnes) et toutes les grandes communautés (un million de personnes ou plus) font appel à des bénévoles. Lorsque ces données ont été compilées pour l'ensemble des États-Unis, une estimation nationale moyenne de 345466 personnes (195 754 SEM) a consacré 1484204 (665 460 SEM) heures de bénévolat en lien avec des activités impliquant les arbres municipaux. Ceci équivaut à 714 (320 SEM) postes à temps plein (2 080 heures par année). Dans l'ensemble, les bénévoles ont réalisé près de $5 \%$ des activités d'entretien des arbres municipaux. Près de 80 $\%$ des municipalités forment leurs bénévoles. La plantation d'arbres (85\% des communautés) était l'activité la plus courante, suivi par l'arrosage des arbres (40\%), les programmes de sensibilisation/éducation (39\%), l'élagage des arbres (28\%) et la collecte de fonds (20 $\%)$. Ces constatations ont été comparées avec les recensements de groupes de population des États-Unis afin de valider si le bénévolat variait en fonction de la taille de la communauté. Les bénévoles étaient plus souvent impliqués dans les communautés caractérisées par un développement important de la foresterie urbaine résultant d'une préoccupation marquée envers le développement durable. Six caractéristiques, ayant une action positive $(+)$ ou négative (-) [un budget adéquat (-), les dépenses par habitant (-), un conseil d’administration spécifique aux arbres $(+)$, le rayonnement $(+)$, un plan stratégique $(+)$ et le nombre total d'emplois $(+)$ ] sur le programme de foresterie municipale permettaient d'anticiper du taux de participation des volontaires dans la gestion de la forêt urbaine.

Zusammenfassung. Der Support von kommunalen Forstoperationen durch eine kultivierte Bürgerbeteiligung basiert auf Freiwillingen und Partnerschaften. Durch einen nationalen Zensus und einer Erhebung zur urbanen Forstaktivität in über 600 Kommunen in den Vereinigten Staaten, fanden die Forscher heraus, dass zwei Drititel der Kommunnen Freiwillige in Baumarbeiten integrieren. Dieses stieg von der Hälfte der kleinen Kommunen (2.500 bis 4.999 Menschen) bis zu allen großen Kommunen (eine Millionen oder mehr Menschen), die Freiwillige involvieren. Bei einer Tabulierung für die Vereinigten Staaten fand man heraus, dass durch- 
schnittlich auf nationaler Ebene 345.466 (195.754 SEM) Freiwillige 1.484.204 (665.460 SEM) Stunden mit kommunalen Baumaktivitäten zubrachten. Das führt zu 714 (320 SEM) Vollzeitstellen (auf einer 2.080 Stundenbasis pro Jahr). Im ganzen vervollständigten die Freiwilligen annähernd $5 \%$ der kommunalen Baumaktivitäten. Annähernd $80 \%$ der Kommunen trainieren ihre Freiwilligen. Baumpflanzen (85\% der Kommune) war die meiste Tätigkeit, gefolgt von Baumwässern (40\%), Achtsamkeits und Fortbildungstraining (39\%), Baumschnitt (28\%), und Mittelbeschaffung (20\%). Die Ergebnisse wurden in Kontrast mit amerikanischen Zensus-Populationsgruppen gesetzt, um diese zu zerlegen, wenn die Freiwilligkeit mit der Größe der Kommunengröße variiert. Freiwillige waren gewöhnlich mehr in Kommunen mit größerer urbaner Forstkapazität, die aus einem Nachhaltigkeits-Index-Ziel abgeleitet wurde, involviert. Sechs Attribute mit einem positiven $(+)$ oder negativen (-) Effekt (adäquates Budget -, Prokopfausgaben -, Baumgremium + , Nutzen +, Strategieplan +, und totale Beschäftigung +) des kommunalen Forstprogramms bestimmten die Freiwilligenpartizipation im urbanen Forstmanagement.

Resumen. Las comunidades cultivan el apoyo ciudadano a las operaciones forestales municipales con la participación de voluntarios y asociaciones. A través de un censo nacional y una encuesta de actividad forestal urbana en más de 660 municipalidades en los Estados Unidos, los investigadores encontraron que dos tercios de todas las comunidades que respondieron involucran voluntarios en actividades de árboles. Esto aumenta de la mitad de las comunidades pequeñas (de 2,500 a 4,999 personas) a todas las comunidades grandes (un millón o más de personas) involucrando voluntarios. Cuando se tabuló para los Estados Unidos, una estimación nacional promedio de 345,466 (195,754 SEM) personas ofreció voluntariamente 1'484,204 (665,460 SEM) horas con actividades de árboles municipales. Esto equivale a 714 (320 SEM) puestos de tiempo completo equivalentes (2.080 horas base de año). En general, los voluntarios completaron casi el 5\% de las actividades de cuidado de árboles municipales. Cerca del $80 \%$ de los municipios capacitan a sus voluntarios. La plantación de árboles (85\% de las comunidades) fue la actividad más común, seguida de riego de árboles (40\%), programas de concientización / educación (39\%), poda de árboles (28\%) y recaudación de fondos (20\%). Los hallazgos se contrastaron con los grupos de población del censo de los EE. UU., con el fin de disociar si el voluntariado variaba según el tamaño de la comunidad. Los voluntarios participaron más comúnmente en comunidades con una mayor capacidad de dasonomía urbana derivada de un índice de sostenibilidad. Seis atributos con un efecto positivo (+) o negativo (presupuesto adecuado -, gasto per cápita -, junta directiva + , proyección + , plan estratégico + , y empleo total + ) del programa forestal municipal predijeron la participación voluntaria en actividades bosque. 